\title{
POLITICAL HEGEMONY AS A MEDIA OF DA'WAH MUHAMMAD BIN ABDUL WAHAB
}

\section{Ms Udin, Irpan}

Mataram Islamic State University

msudin@uinmataram.ac.id, irpan@uinmataram.ac.id

\begin{abstract}
Da'wah is an activity that is inherent in humans, especially for a Muslim or Muslimah. In this study, the researcher describes Muhammad Bin Abdul Wahab's da'wah method using political media as a propaganda medium, namely by collaborating with the head of state Ibn Saud who has the same expansion interests, namely regional expansion (Ibn Saud) and teaching expansion (Muhammad Bin Abdul Wahab). Before making the collaborating, Muhammad Bin Abdul Wahab received the resistance from the community and even his own family, but after collaborating with Ibn Saud, Muhammad Bin Abdul Wahab's da'wah activities got a new spirit, especially Ibn Saud was a warlord so that Muhammad Bin Abdul Wahab's preaching space was wide open in the Arabic land.
\end{abstract}

Key Word: Da'wah Method, State Hegemony, Politics, Muhammad Bin Abdul Wahab

\section{A. Introduction}

The issue of da'wah is a problem that is inherent in every human being to carry out or express the ideas so that they are accepted by everyone for a change and progress that is beneficial in this world and in the hereafter. Da'wah is an effort to invite someone to something good, but not all da'wah activities can be accepted by the community. Da'wah activities have received a lot of rejection and opposition. The rejection and opposition may be caused by the da'wah method that is not in accordance with the conditions of the community or the refusal may occur due to the da'wah message conveyed by a Da'i offending people's feelings. 
In the Islamic world, ideas of da'wah have emerged for a renewal of monotheism in the mid 1250-1800 AD. The idea of purification of Islam emerged as a response to socio-political and monotheistic understanding among Muslims. Muhammad bin Abdul Wahab had great ideas and ambitions to carry out a da'wah movement because he saw that Islamic practices in his birthplace were no longer based on monotheism, even Muhammad Bin Abdul Wahab saw that these personal practices had reached the point of shirk. With such religious conditions, Muhammad Bin Abdul Wahab had the idea of carrying out a massive da'wah movement because the condition of understanding monotheism could no longer be tolerated. The efforts of the da'wah movement carried out by Muhammad Bin Abdul Wahab met serious resistance from the residents in his hometown and even his family rejected the teachings brought by Muhammad Bin Abdul Wahab which led to his expulsion.

To be able to freely carry out the da'wah movement, Muhammad Bin Abdul Wahab tried to use politics or the power of the state and power as a medium of da'wah by meeting Ibn Saud to carry out the same movement, namely the regional expansion movement and the understanding of Islamic purification. Ibn Saud was the ruler as well as the local elite in the area, so Muhammad Bin Abdul Wahab's da'wah movement and Ibn Saud's political movement became a great force to be used as propaganda media.

\section{B. Research Method}

This research uses the library review research method, the literature review research method is in the form of theoretical studies that are relevant to the research. In this section, an assessment of the concepts and theories used is carried out based on 
the available literature, especially from articles published in various scientific journals. Literature review serves to build concepts or theories that form the basis of studies in research.1

Literature review or literature study is an activity that is required in research, especially academic research whose main goal is to develop theoretical aspects as well as aspects of practical benefits. 2 By using biblical research methods, researchers in this journal look for data related to the movement of Muhammad Bin Abdul Wahab and the pattern of Ibn Saud's state hegemony.

\section{Discussion}

\section{Political Power and State Hegemony as Da'wah Media}

1) Understanding Politics

In Ancient Greek, the word politics is taken from the word "polis" which means city or city with the meaning of the ruling state.3 Along with that, Miriam Budiardjo explained that politics includes several meanings as follows:

a. The state (state), means an organization in an area that has the highest legal power and is obeyed by its people.

b. Power, namely the ability of a person or group to influence the behavior of other people or groups as desired. In this case, politics is related to all activities in seizing and maintaining power.

\footnotetext{
${ }^{1}$ V.Wiratna Sujarweni,Metodeologi Penelitian ( Yogyakarta : Pustaka Baru Perss, 2014), h.57.

${ }^{2}$ Sukardi,Metodologi Penelitian Pendidikan Kompetensi dan Praktiknya (Jakarata : PT Bumi Aksara, 2013), hlm.33

${ }^{3}$ Abd. Muin Salim, Konsep Politik Dalam Al-Quran, Jakarta: PT. Raja GrafindoPersada, 1994, hlm. 34.
} 
c. Policy (Policy), namely all actions related to collective efforts for collective goals that are carried out according to a certain, organized and directed plan that is diligently and continuously trying to produce and maintain or change the social structure.4

Ramlan Surbakti said that there are at least five views on politics. First, politics is the efforts taken by citizens to discuss and realize the common good. Second, politics is everything related to the administration of the state and government. Third, politics are all activities directed at seeking and maintaining power in society. Fourth, politics are all activities related to the formulation and implementation of public policies. Fifth, politics as a conflict in order to find or maintain sources that are considered important.5 2) State Hegemony

To be able to see how the power of Ibn Saud's hegemony as a medium of da'wah used by Muhammad bin Abdul Wahab, the author will explain how the concept of state hegemony is. The concept of hegemony used by the author is the concept of hegemony according to Gramsci.

Gramsci acknowledged that in society there are always those who rule and those who are ruled. Starting from this condition, Gramsci saw, if the prince was to rule effectively, then the chosen path would minimize the existence of the people and at the same time the prince had to create a spontaneous obedience from the ruler. In short, Gramsci formulated in a sentence, "how to create a hegemony". Hegemony is a chain

${ }^{4}$. Miriam Budihardjo, Dasar-dasar Ilmu Politik, Jakarta: PT. Gramedia, 2002, hlm. 8.

${ }^{5}$ Ng. Philipus dan Nurul Aini, Sosiologi dan Politik (Jakarta: PT Raja Grafindo Persada, 2006), hlm. 93 
of victories that is obtained through a consensus mechanism rather than through oppression of other social classes.

There are various ways that are used, for example through existing institutions in society that determine directly or indirectly the cognitive elements of society. Therefore, hegemony is essentially an attempt to lead people to assess and view social problems within a defined framework. Hegemony also refers to the ideological position of one or more groups or classes in civil society that is superior to others.6 The three categories of hegemony according to Gramsci include;

1). People conform perhaps out of fear of the consequences if they do not conform. In this case, conformity is pursued through fearful suppression and sanctions.

2). People who conform may be accustomed to following goals in certain ways. Conformity in this case is a matter of participation which is not reflected in a fixed form of activity, because people adhere to certain patterns of behavior and it is rarely possible to refuse.

3). Conformity that arises from behavior has levels of awareness and agreement with certain elements in society.7

\section{Biography of Muhammad Ibn Abdul Wahab and His Thoughts}

Wahhabism was attributed to Sheikh Muhammad bin Abdul Wahab from Najd. This attribution was derived from the name of his father, Abdul Wahab. As scientists put it, this is the reason why this understanding was not attributed to Sheikh Muhammad $120-121$

${ }^{6}$ Nezar Patria dan Andi Arif. Antonio Gramsci Negara Dan Hegomoni, Yogyakarta: Pustaka Pelajar, hlm.

${ }^{7}$ Nezar Patria dan Andi Arif. Antonio Gramsci Negara..., hlm 127 
himself and was called "Muhammadiyah" because of concerns from followers of this belief that they were considered to have some kind of relationship with the Prophet Muhammad and could misuse this ordination.

Sheikh Muhammad was born in $1115 \mathrm{H} / 1703$ AD in the city of Uyainah which is located in the Najd region.8 He came from a very respectable and educated family. His father, Sheikh Abdul Wahhab bin Sulaiman, was the head of the local religious office. While his grandfather, Shaykh Sulaiman bin Ali, the grand mufti, where the people of Najed asked everything related to religious matters. This reality is not surprising, when Ibn Abdul Wahab grew up to become a formidable scholar like his grandfather.9 Muhammad Ibn Abdul Wahhab grew up as a person who was quite intelligent, able to memorize the Qur'an at a very young age, 10 years. He also read a lot of books of interpretation, hadith and fiqh. From the beginning Ibn Abdul Wahhab was very interested in the works compiled by previous scholars, especially the work of Ibn Taimiyah (d.1328) and his student Ibn Qoyyim Al Jauziyyah. Almost all the contents of the books by the scholars from beginning to end can be studied and mastered. 10

Muhammad Ibn Abdul Wahab's deep interest in the teachings of Ahmad bin Hanbal11 and Ibn Taymiyyah 12 was very pervasive in him. According to Adi Nugroho,

\footnotetext{
${ }^{8}$. Najed is a country or city in the Arabian Peninsula that is still pure in its Islamic level, so that the hands of the Ottoman Turks who controlled Saudi Arabia and Egypt at that time did not touch it much. hlm. 50 .

See Suharsono, Gerakan Intelektual, Ijtihad untuk Masa Depan Umat, Yogyakarta: Al-Islamiyah, 1992,

9. Muhammad Ibnu Abdul Wahhab, Tegakkan Tauhid, Tumbangkan Syirik, Muhammad Muhaimin (Penerjemah), Yogyakarta: Mitra Pustaka, 2000, hlm. ix.

10. Muhammad Ibnu Abdul Wahhab. Tegakkan Tauhid, Tumbangkan Syirik, hlm. x

11. Ahmad bin Hanbal, in full Ahmad bin Muhammad bin Hanbal was born in Baghdad, in the month of Rabiul Awal $164 \mathrm{H} /$ November $780 \mathrm{AD}$ and died in the same place, 12 Rabiul Awal 241 H / July 31, 855 AD. Hanbali is known as the founder of the Hanabilah school, as well as the smartest student and the brightest among the students of Imam Shafii. Hanbali also continued the As Syafii method, especially with regard to the notion of "riwayah". As a child, Hanbali studied from several areas, such as Baghdad, Sham, Hijaz and Yemen. Until now his
} 
this description makes Muhammad Ibn Abdul Wahhab a duplicate of Ibn Taimiyah, especially in the aspect of purification of monotheism. Everything that was dreamed of by Ibn Taymiyyah during his life has been rewarded with the glory of Ibn Abdul Wahhab. Apart from being a pre-modernist revivalist Islamic reformer 13 and puritan da'wah figure, Muhammad Ibn Abdul Wahhab was also active in writing, among his works are Kitab al-Tawhid, Kasyf al-Syyubhat, Kitab al-Kabair, Mukhtasar sirat Al-Rasul , Masa'il Al-Jahiliah, Usul Al-Iman, Fadai'I Al-Qur'an, Fadai'I Al-Islam, Majmu'al AlHadith, Mukhtasar Al-Insaf wa Al-Syarh Al-Kabair, Al- Usul al-Tsalatsah, Adab al-Masyi ila al-Salah, Lam'usy Syihab fi Syarah Muhammad ibn Abdul Wahhab wa mazhabih, Tafsir Al-Fatihah, Tafsir Al-Shahadah wa Ma'rifatullah, and Al-taudlih 'An Tauhid almorality. 14

madzab still exists and attracts a large following, especially Saudi Arabia. Nurkholis Madjid, Islam Doktrin dan Peradaban, Jakarta: Paramadina, 1993, hlm. 170

${ }_{12}$ Abu Abbas Ahmad bin Abdu Al Halim bin Abdu Al Salam Abdullah bin Muhammad bin Taimiyah was born in Haran, near Damascus, Syria in 661 H/1263 AD. His father was Abu Al Mahasin Abdu Al Halama and his grandfather was Shaykh Al Islam Abu Al Barakat Abdu Al Salam bin Abdullah, both prominent scholars from the Hanbali school. As a follower of the Hanbali school who is steadfast and has broad religious insight, Taimiyah is very persistent in defending the opening of the door to ijtihad, vehemently opposes heresy, superstition, Sufi mysticism and tries to destroy the remnants of philosophy in the science of mantiq and develop a more empirical view. Because of his harsh and opposing views, Taimiyah went to prison many times and even died in that place in $727 \mathrm{H} / 1328 \mathrm{AD}$. When he was trusted as the great teacher in the field of hadith to replace his father, Taimiyah was accused of being an atheist, because his fatwas contradicted his opinion. while other schools, especially Shafi'i. These fatwas, among others, about thalaq, prohibition of visiting graves and disliking mystical understanding. His books include Al Syiyasah Al Syariyah fi Islah Ar Rai wa Ar Rai'yah., Muwafaqotu Sharihul Ma'qulli Shahihil Manqué, Al Answerus Sahih liman Baddala Dinal Masih, Ar Rasail wal Masail, Al Aqidatul Waasitiyah. See Suharsono, Munawir Sjadzali, Islam dan Tata Negara, Jakarta: Universitas Indonesia, 1991, hlm 79-82.

${ }^{13}$ The movement brought by Muhammad Ibn Abdul Wahhab has four characteristics. First, a deep concern for the moral decline of the Muslim community. Second, it urges to return to the original Islam and try to carry out ijtihad. Third, get rid of a burdensome view of the nature of destiny. Fourth, call for revivalists through force of arms (jihad) if necessary. However, the general impression from Western scholars is that the reforms brought by Muhammad Ibn Abdul Wahhab are literalist, even fundamentalist. In fact, Islamic style fundamentalists are very different from Christianity. In Christianity fundamentalism is a reaction against the modern interpretation (ijtihad) of the Bible. While in Islam, fundamentalists oppose blind taqlid to tradition and open ijtihad. read: Harun Nasution dan Azumardi Azra (penyunting), Perkembangan Modern dalam Islam, Jakarta: Obor Indonesia, 1985, hlm. 22-23.

${ }^{14}$ A. Hasjmy,.Sejarah Kebudayaan Islam, Jakarta: Bulan Bintang, 1985, hlm. 347 
Muhammad Ibn Abdul Wahab has several main teachings that become the paradigm of thinking. Tawhid, according to Ibn Abdul Wahab, is basically devotion (worship) only to Allah in a way that truly unites Him. He divides monotheism into three. First, the monotheism rububiah concerning the oneness of God as the creator of all things independent of all kinds of influences and causes. Second, monotheism asma wa attributes related to the attestation of the name and attributes of Allah which are different from His creatures. Third, divine monotheism which is related to the oneness of Allah as the God to be worshipped.

According to Abdul Wahab, most Muslims only follow the first two monotheisms, while the divine monotheism is widely distorted and even rejected by Muslims, even though this type of monotheism is the most important to be maintained and practiced. 15 This view of monotheism put forward by Ibn Abdul Wahab, when traced, is actually the thought of the Salafi school, especially Ibn Taimiyah as the main character.

Divine monotheism, which is essentially oneness and worship of Allah, will be realized if at least two things are fulfilled, namely first, only worshiping Allah alone and not acknowledging the existence of divinity for other than Allah, whoever includes creatures to be worshiped with Allah. means he has committed polytheism: he has partnered with Allah with something other than Allah in worship, even though he believes in the oneness of Allah as the creator of the universe. Second, worshiping and worshiping Allah must be in accordance with the method prescribed by Allah through

${ }^{15}$ Agus Moh. Najib, Gerakan Wahabi di Indonesia Dialog dan Keritik, Bina Harfa; 2009, hlm. 3-5 
the Prophet. (This worship is either obligatory, sunnah or permissible) should be solely intended as obedience to the expression of gratitude only to Allah. 16

Ibn Abdul Wahab's thinking looks very extreme because everyone who is considered contradictory and does not practice pure monotheism as he wishes is immediately labeled as an infidel or polytheist who can be killed. This radical view was opposed by many parties and caused a commotion in society, so that then Ibn Abdul Wahab was expelled by the local authorities. He also left Najed and sought refuge in Dar'iyah, an area controlled by Muhammad Ibn Saud.

Ibn Abdul Wahab was interested in asking for protection from Ibn Saud because ibn Saud was seen as having a moderate mind, in addition to having great ambitions to dominate the Arabian mainland. In 1744, the two of them agreed to cooperate in carrying out a movement with two goals at once, namely establishing a state and spreading Wahhabism. In other words, a ruler and a cleric work together to establish a Wahhabi-State (the Saudi-Wahhabi state). in fact, the bond between the two became even closer, because Ibn Abdul Wahab married Ibn Saud's daughter.17

The Wahhabis and Ibu Abdul Wahab themselves state that their thinking comes from the Salafi group as developed by Ibn Taimiyah. This Salafi thought, according to the Wahhabis, is a thought that follows the Salaf al-saleh from the companions and tabi'in, who always follow the Sunnah of the Prophet. Therefore, the Wahhabis stated that they were a fiqh najiah (group of survivors) from among the people of the Prophet Muhammad because they always consistently used the manhaj

${ }^{16}$ Agus Moh. Najib, Gerakan Wahabi di Indonesia Dialog dan Keritik. hlm. 6
${ }^{17}$ Agus Moh. Najib, Gerakan Wahabi di Indonesia Dialog dan Keritik, hlm. 8 
(method) sunnah sahihah. Ahamad Bin Hambal as a role model imam and declares that he is a true sunnah group, because Imam Ahmad Bin Hanbal is the most prominent sunnah expert figure.

The Salafis with the main character Ibn Taimiyah stated that in understanding the Islamic creed, most scholars used philosophical methods and rational thought. This was mainly done by the Mu'tazilah and then the Maturidiah, Asy'ariah and other groups. The method of the Salafi school is different from these schools, they follow the methods of the companions and tabi'in who are self-sufficient and do not question details about the faith. Because of the scriptural method, the Salafi and Wahhabi schools understand and decipher the texts of the Qur'an and the Prophet's Hadith textually and literally, both in the field of fiqh and others.

However, if one observes the Salafi group, especially in the hands of Ibn Taimiyah, they have their own thoughts on kalam (Islamic theology) and argue with their opponents. The Wahhabis, as stated above, claim that their thinking is a continuation of the Salafi group of Ibn Taimiyah, which is believed to have originated from Ibn Hanbal who is said to have presented the thoughts of the Companions and Tabi'in (salaf alsaleh). 18

\section{Forms of Political Hegemony as a Da'wah Media}

When viewed from the political understanding, it can be seen that through the process of cooperation with ibn Saud, Muhammad Bin Abdul Wahab's da'wah activities have easy access and have political power that can be easily used to be able to disseminate ideas, opinion and teachings. The symbiotic relationship between Ibn Saud

${ }^{18}$ Agus Moh. Najib, Gerakan Wahabi di Indonesia Dialog dan Keritik, hlm. 9-12 
and Abdul Wahab is a relationship that is an important factor in the da'wah movement of Abdul Wahab. Abdul Wahab needed the power of Ibn Saud to help spread his teachings, with his power of course able to influence the community through his political policies as the ruler of the local elite in the Dar'iyah region. In its development, the Wahhabi movement became strong when it received political support from Muhammad bin Sa'ûd (Amir Muhammad bin Sa'ûd, ruler of Dar'iyyah). 19

With teachings taken from a textual understanding and trying to be applied by means of political coercion through the power of Ibn Saud, the Wahhabi movement from the beginning was opposed to many. Many residents of Uyainah, the birthplace of Ibn Abdul Wahab himself, rejected and opposed his teachings. Even Ibn Abdul Wahab's close relatives such as Sulaiman (his brother) and Abdullah Bin Husayn (his cousin) were against him. His conflict with Abdullah Bin Husayn caused bloodshed among the Bani Tamim in Yamamah. This is according to one narration, which led to being expelled from Uyainah.

Then from Uyainah Ibn Abdul Wahab went to Dar'iyah to cooperate with Ibn Saud, the chief and ruler there. In 1744 , as already stated, the two agreed to cooperate in carrying out a movement with two goals at once, namely establishing a state and spreading Wahhabism. The Saudi-wahabi movement has two strategic points, namely radical religious sects and political power to expand territory and spread teachings, so that this understanding has progressed quite rapidly. The expansion of the SaudiWahhabi territory disturbed the Ottoman Sultan, Mahmud II (1785-1839), who ruled the

${ }^{19}$ Zainal Abidin Syihab, Wahabi dan Reformasi Islam Internasional, Jakarta: Pustaka Dian, 1986, hlm. 25. 
Arab region at that time. He then ordered the governor of Egypt Muhammad Ali to quell this Saudi-Wahhabi revolt. With his military renewal, Muhammad Ali's troops were able to defeat this Saudi-Wahhabi movement.

During the expansion of territory and the spread of these teachings, the Wahhabi movement attacked, damaged and eradicated community customs which were considered heretical and contrary to monotheism. In the context of purification of monotheism, they destroy a lot of symbols that are considered to cause polytheism such as tombs, decorations and cloth in mosques and the Kaaba. They also damaged the grave of Husein Ibn Ali Ibn Abi Talib in Karbala, which was visited by many Shiites. The Sudi-Wahhabi state, as it was originally formed, is based on the Saudi leadership and the Wahhabi mission together. The descendants of Ibn Abdul Wahab who are called "the sheikh's family," until now have played an important role as state advisors.

Wahhabism is a fundamental movement of modern "ism" in Islam, which seeks to create a society with traditions and behavior in accordance with the textual teachings of the Qur'an and Sunnah. To create society, they established the State as a coercion, the Wahhabis have imposed their interpretation on other groups because they cannot accept the existence of a plurality of opinions in understanding religion. This is the difference in the method of spreading the Wahhabis with Ibn Taimiyah or the Salafi group in general. Salafis spread their teachings by exchanging ideas and debating, both orally and in writing. But the Wahhabis spread their teachings by force and use politics and power as tools. 20

${ }^{20}$ Agus Moh. Najib, Gerakan Wahabi di Indonesia Dialog dan Keritik, hlm. 17-21 
If Taqiyuddin Ahmad Ibn Taimmiyyah (1263-1328 AD), as the builder of the Salaf school, instilled ideas by writing books and holding exchanges of ideas and debates, then the Wahhabis in broadcasting their teachings as heretics must be fought, in accordance with the teachings of the Wahhabis, the principle of "amal ma'ruf nahi munkar". Because of their radicalism, Wahhabism is seen as the embodiment of the Khawarij. 21

Muhammad bin Abdul Wahab felt for himself that the superstition that befell the Muslims in his country, was not only limited to the worship of graves, as places of pious people, and giving vows because of it, but also spread to the worship of inanimate objects. Some of the country's children at the place of birth, namely Yamamah or Riadoh now, worship a date tree because they are considered by them to provide a mate. This act was seen by him as an act of shirk. Therefore, he called for not visiting the grave, except to look for examples, not to seek intercession and tawassulat. The first act of violence he did was cutting a date palm tree which was considered sacred. Then every time the Wahhabis entered a place or city, they dismantled graves, razed them to the ground, even mosques were demolished, so European writers called them "dismantling places of worship" (huddamul ma'abid).

Their actions were not limited to the demolition of the graves of saints or ordinary pious people, but went further. When they were able to take over Mecca, many historical places were destroyed, such as the birthplace of the Prophet Muhammad, Abu Bakr ra., and Ali ra. When they arrived at Medina, the graves of the Prophet's

${ }^{21}$ Sahilun A. Nasir, Pemikiran Kalam (Teologi Islam) Sejarah, Ajaran dan Perkembangannya, PT Rajagrafindo Persada, hlm. 293 
companions at Baqi' were razed to the ground and marked enough. The Prophet's grave itself almost suffered the same fate, if they were not afraid of the anger of the Islamic world against the Prophet's grave. They simply removed the existing decorations and forbade the replacement of the sheath with a new one.

However, the Wahhabi movement with a religious character and the backbone of the power of King Muhammad bin Saud, was seen by the Ottoman rulers (caliphates) in Turkey who ruled Arabia at that time, as resistance and rebellion against his rule. Therefore, the ruler sent his army to Arabia to crush the movement. 22

If you look closely, actually there is a positive side that can be shown from the Wahhabi school, for example in terms of preaching. Da'wah is an effort to invite (encourage) people to do good and follow instructions, to tell them to do good and forbid from evil deeds so that they get the good of this world and the hereafter. 23 But then it must be realized that the initial goal of Islamic da'wah was to improve human behavior (especially the behavior of Muslims). In terms of da'wah, it is called Tamkinut Taghyir (trying for change); even using the term Tamkinul Inqilab (trying to change the turning point drastically). It often happens, da'wah that prioritizes gentleness (Amar Ma'ruf) alone, without being accompanied by a firm attitude towards evil, can be accepted everywhere, like the model of the Tablighi Jamaat's da'wah. Because the human heart is basically happy with tenderness and hard to accept violence. However, such da'wah is generally not able to change the culture of the people who are already strong in

22. Sahilun A. Nasir, Pemikiran Kalam (Teologi Islam) Sejarah, Ajaran dan Perkembangannya, hlm. 294-

${ }^{23}$ Muhammad Sulthon, Desain Ilmu Dakwah, Yogyakarta: Pustaka Pelajar, hlm. 9. 
standing on secular principles, immorality, and lust. There, Islamic values are accepted, but limited to individual, family or group experience.

Here the da'wah of Shaykh Muhammad shows its distinctive characteristics. Since appearing in the 18th century until the 21 st century, this da'wah has been frank, firm in upholding principles, not compromising against deviations. This character causes internal and external conflicts, but is also able to change the situation of society, even the political order, the evidence is the reality in Saudi Arabia, Afghanistan under the Taliban, in Algeria when the FIS power dominates, in Yemen, Pakistan and Sudan. In these countries the da'wah of the Shaykh has a real influence.

The original essence of the movement of Shaykh Muhammad and his followers is the Islamic da'wah movement like other da'wah movements. If there are certain characteristics in this da'wah movement, it is a distinctive character that distinguishes it from other da'wah movements. As for the merits of da'wah, it will be proven through the results of changes in the ummah. Every da'wah movement has the potential for wrong and error, and it is the duty of every Muslim to advise him in truth, patience and compassion. 24

On the other hand, Sufis and Shiites also reject Wahhabi teachings in their preaching, because in Wahhabi da'wah there is a very strong denial of grave worship, worship of the graves of saints, seeking for "sacred" graves and so on. Meanwhile, such affairs among Sufis and Shiites can be considered as "the lifeblood of religion". Logically, if their spiritual source of religion is disturbed, they are clearly angry.

${ }^{24}$ Am. Waskito, Bersikap Adil Kepada Wahabi, Pustaka Al-Kautsar; 2011, hlm. 182-184 
Moreover, it has become an open secret, in the area of "sacred" graves or historical remains, there is often a lucrative business turnover.

There are several factors that make Sufi Islam and Shia Islam not accept and oppose the da'wah teachings conveyed by Muhammad Bin Abdul Wahab, that's why Muhammad Bin Abdul Wahab considers what Sufi and Shia Islam believes and practices is something that is very contrary to the teachings of monotheism which brought by the prophet Muhammad SAW. Sufi and Shia Islamic teachings and beliefs are considered shirk.

Shaykh Salim bin 'led Al-Hilaly quoted by Waskito mentions that there are four similarities between Sufi teachings and Shia teachings. First, both claims to have special knowledge. The Shia claim to have special knowledge that the Muslims do not have, because that knowledge is only the specialty of the people of the Bait Nabi. The Sufis admit that they have the knowledge of Ladunni which was directly revealed by Allah to them, outside of the knowledge of Shari'a. Abu Yazid Al-Busthami once said "we have sailed the sea, while the prophets were only able to be on its shores." Second, they both glorify their priests or leaders. The Shia glorify the Imams, even worship them. The Sufis glorify their saints or murshids.

Among them there are the so-called wali aqthab, wali autad, wali abdal, wali ghauts. Both the priest and the wali are considered to have the power of rubbubiyyah (divinity). Third, they both believe that Islam is divided into zahir and inner. They call the knowledge of the Shari'a a science of zahir; while the knowledge understood by the priest / guardian is the real science, namely the science of the mind. Sometimes they 
call the fourth "science of the Shari'a" and "the science of nature," both of them cult of graves. Both the Shia and the Sufi tariqat take great pleasure in worshiping graves. The Sufis claim that the tomb of Ma'ruf Al-Karkhi, one of the Sufi rulers, is a panacea. 25

As explained by the author above, after Muhammad Bin Abdul Wahab carried out a da'wah movement at his birthplace, he was expelled by local residents, Muhammad bin Abdul Wahab went to Dar'iyah and cooperated with Ibn Saud. Ibn Saud certainly had great political power to influence his people and this political power was utilized by Muhammad bin Abdul Wahab as a relevant da'wah medium in his time, besides that Ibn Saud also had great ambitions to expand the territory so that cooperation between the two could be agreed and agreed upon win-win solution.

The forms of state hegemony against its people during the time of Muhammad Bin Abdul Wahab are as follows:

1. People may conform because they are afraid of the consequences if they do not conform. In this case, conformity is achieved through suppression and fearful sanctions. It can be seen that the political power that is built leads to the hegemony of the State over the religious understanding of its people. Hegemony has an important role to influence the people in the country. This condition is also a factor supporting the success of the da'wah carried out by Muhammad Bin Abdul Wahab by utilizing his collaboration with Ibn Saud who has a local elite position in the Dar'iyah area. The cooperation between the two can be seen until now by making the descendants of Muhammad Bin Abdul Wahab as an advisor to the king in Saudi Arabia.

${ }^{25}$ Am. Waskito, Bersikap Adil..., hlm. 366-368 
The Wahhabi movement itself was originally an Islamic purification movement, but after an agreement was reached between Muhammad bin Abdul Wahhab and Muhammad bin Saud in 1744 AD, the Wahhabi movement turned into a political movement, but in the religious field. That is, although it has turned into a political movement, this Wahhabi movement has not abandoned their original mission, namely as a movement for the purification of Islam. 26

Abdul Wahhab cooperated in a systematic and mutually beneficial manner with the Saud family. Within a year of arriving in Dariyah, Abdul Wahhab gained a following of almost the entire population of the city. Abdul Wahhab's followers continued to grow, meanwhile, the Sa'ud family, which almost all of their lives were involved in wars with other tribal chiefs for 28 years, slowly but surely entered glory. 27

If the da'wah movement of Muhammad Bin Abdul Wahab is seen from the hegemony of the State by Gramsci, it will be seen that the power of the leader of power has a very large influence as a public communicator to transform ideas and opinion by exploiting his position to be able to influence society ideologically or politically. The da'wah method used by Muhammad Bin Abdul Wahab by using power as a medium to hegemony public perception is a method that is considered appropriate to reduce public resistance to the rejection of the ideas and opinion that Muhammad Bin Abdul Wahab wants to convey. In the end, the method taken by Muhammad Ibn Abdul Wahab by working with Ibn Saud who was a warlord 28 made the local people accept him because

${ }^{26}$ Ali Mufrodi, Islam Di Kawasan Kebudayaan Arab, Tanggerang Selatan: Logos Wacana Ilmu, 1997, hlm. 151 2006), h. 245.

${ }^{27}$ Herry Muhammad, DKK, Tokoh-Tokoh Islam Yang Berpengaruh Abad 20, (Jakarta: Gema Insani,

${ }^{28}$ IAIN Syarif Hidayatullah, Ensiklopedi Islam Indonesia, Jakarta: Jambatan, 1992, hal. 975 
the people were afraid of the consequences they would face if they did not obey the government. 29

The government as the policy holder is used as a strong support in launching Muhammad Ibn Abdul Wahab's da'wah so that some people accept wholeheartedly what the government's policy is. But in fact, it was not only government policies that led to the acceptance of Wahhabi ideology but also because Ibn Saud was a warlord, so that psychologically some people felt pressured and fearful if they did resistance to the policy.

2. People who conform may be accustomed to following goals in certain ways. Conformity in this case is a matter of participation which is not reflected in a fixed form of activity, because people adhere to certain patterns of behavior and it is rarely possible to refuse.

On the other hand, there are also some people who only accept it but in practice they still never want to follow it. In the sense that they accept it because it is a government policy and not in the sense of an ideological doctrine. This section is mostly filled by Sufis and Shiites who have long rejected the ideology offered by Muhammad Ibn Abdul Wahab. Here we see the policies of the Sufis, they continued to follow the policies of the government at that time, but they did not apply the entire Wahhabi doctrine which became the state ideology at that time. Because the Sufis have patience and gentleness, the Sufis do not want war and conflict.

${ }^{29}$ Nezar Patria dan Andi Arif. Antonio Gramsci Negara..., hlm. 120 
3. Conformity that arises from behavior has levels of awareness and agreement with certain elements in society.

Because many parties opposed him, of course he needed strong support to carry out reforms to Muslims at that time. Therefore, Muhammad bin Abdul Wahhab then made an agreement and collaborated with the governor of the Dar'iyah region, namely Muhammad bin Saud, to spread da'wah by word of mouth and the sword simultaneously. So, in a short time the governor and Muhammad bin Abdul Wahhab were able to control the areas of Mecca and Medina, even the Arabian Peninsula in 1802M. 30

In this last description of the hegemony of the State of Ibn Saud to cooperate with Muhammad bin Abdul Wahab in the mission of regional expansion and spreading da'wah. Conformity is clearly visible between the family group of Ibn Saud and the family group of Muhammad bin Abdul Wahab where all forms of agreement and approval between the two are symbiotic, namely mutually beneficial cooperation between the two. Before collaborating with Ibn Saud, Muhammad bin Abdul Wahab's da'wah movement experienced difficulties with rejection and resistance by the people of Uyainah, his own birthplace. Even Ibn Abdul Wahab's close relatives such as Suliaman (his brother) and Abdullah Bin Husain (his cousin) were against it. The conflict with Abdullah bin Husayn caused bloodshed among the Bani Tamim in Yamamah. 31

After Muhammad bin Abdul met Ibn Saud to cooperate in carrying out da'wah missions, Muhammad bin Abdul Wahab's ideas about the purification of Islam were 113

${ }^{30}$ Husain Ahmad Amin, 100 Tokoh Dalam Sejarah Islam, Bandung: PT Remaja Rosda Karya, 1995, hlm.

${ }^{31}$. Agus Moh. Najib, Gerakan Wahabi di Indonesia Dialog dan Keritik, Bina Harfa; 2009, hlm 17 
acceptable to his family. The acceptance of Abdul Wahab's da'wah can be seen until now, namely with the agreement agreed upon by both of them by making family or descendants Muhammad Bin Abdul Wahab as advisor to the king.

\section{Conclusion}

With the descriptions of the discussion above, it can be concluded that to carry out a da'wah activity it is very important for a da'i to think about the impact that will arise if the message of da'wah is delivered to certain community conditions, therefore a method or media of da'wah is very important, its role is to determine Mad'u's response to the message to be conveyed by the preacher. Muhammad Bin Abbdul Wahab used political power, the state and the rulers as a medium to carry out his da'wah activities, thus resistance and rejection of the message of da'wah can be minimized unlike before Muhammad Bin Abdul Wahab before collaborating with Ibn Saud Muhammad bin Abdul Wahab's activities received resistance from the community and even his closest relatives did not agree with the idea of purification of Islam by Muhammad Bin Abdul Wahab, which resulted in his expulsion.

Political hegemony during Abdul Wahab's time can be concluded as follows. After Abdul Wahab carried out a symbiotic mutualism collaboration with Ibn Saud, da'wah activities to purify the teachings of monotheism could be well received without any resistance and rejection by the Dar'iyah community and the surrounding areas due to the existence of Ibn Saud's power in these areas. So, whatever the king said it was a must for the people to accept the king's decision. Ibn Saud's family, even Ibn Saud Himself was known by the public as warlords to continue to expand their territory. 
Because ibn Saud and his family were busy fighting, psychologically the people were afraid to accept the consequences if they refused the teachings of Muhammad Bin Abdul Wahab which had the permission and support of Ibn Saud.

On the other hand, before collaborating with Ibn Saud, the preaching of Abdul Wahab was rejected by his own family until there was war and bloodshed, but after cooperating with Ibn Saud, conformity was created between the family groups of Ibn Saud and Abdul Wahab to work together in regional expansion. while at the same time carrying out a da'wah movement for the purification of Islam. The conformity of the family of Ibn Saud and Muhammad bin Abdul Wahab is clearly visible to this day, namely by making the Saud family the king of Saudi Arabia and the family of Muhammad bin Abdul Wahab as advisors to the king of Saudi Arabia. 


\section{Bibliography}

A. Nasir, Sahilun, Pemikiran Kalam (Teologi Islam) Sejarah, Ajaran dan Perkembangannya, PT Rajagrafindo Persada.

Abdul Wahhab, Muhammad Ibnu, Tegakkan Tauhid, Tumbangkan Syirik, Muhammad Muhaimin (Penerjemah). Yogyakarta: Mitra Pustaka, 2000.

Abidin Syihab, Zainal, Wahabi dan Reformasi Islam Internasional, Jakarta: Pustaka Dian, 1986.

Ahmad Amin, Husain, 100 Tokoh Dalam Sejarah Islam, Bandung: PT Remaja Rosda Karya, 1995.

Budihardjo, Miriam, Dasar-dasar IImu Politik, Jakarta: PT. Gramedia, 2002.

Hasjmy, A., Sejarah Kebudayaan Islam. Jakarta: Bulan Bintang, 1985.

Herry, Muhammad, dkk., Tokoh-Tokoh Islam Yang Berpengaruh Abad 20, Jakarta: Gema Insani, 2006

Madjid, Nurkholis, Islam Doktrin dan Peradaban. Jakarta: Paramadina, 1993.

Moh. Najib, Agus, Gerakan Wahabi di Indonesia Dialog dan Keritik, t.t: Bina Harfa; 2009.

Mufrodi, Ali, Islam Di Kawasan Kebudayaan Arab, Tanggerang Selatan: Logos Wacana IImu, 1997.

Nasution, Harun dan Azumardi Azra (penyunting), Perkembangan Modern dalam Islam. Jakarta: Obor Indonesia, 1985.

Ng. Philipus dan Nurul Aini, Sosiologi dan Politik Jakarta: PT Raja Grafindo Persada, 2006

Patria, Nezar dan Andi Arif. Antonio Gramsci Negara Dan Hegomoni, Yogyakarta; Pustaka Pelajar.

Salim, Abd. Muin, Konsep Politik Dalam Al-Quran, Jakarta: PT. Raja GrafindoPersada, 1994.

Suharsono, Gerakan Intelektual, ljtihad untuk Masa Depan Umat, Yogyakarta: Al-Islamiyah, 1992.

Suharsono, Munawir Sjadzali, Islam dan Tata Negara, Jakarta: Universitas Indonesia, 1991.

Sulthon, Muhammad, Desain IImu Dakwah, Yogyakarta: Pustaka Pelajar. 
Waskito, Am, Bersikap Adil Kepada Wahabi, Pustaka Al-Kautsar; 2011. 